\title{
Istanbul 2005
}

\author{
By Gönül Dönmez-Colin
}

Fall 2005 Issue of KINEMA

\section{ISTANBUL INTERNATIONAL FILM FESTIVAL 2005}

$24^{\text {th }}$ Istanbul Film Festival (April 2-17, 2005), which can be defined as a Festival of Festivals carried the usual format that has had positive audience response over the years with minor adjustments. The International Competition was comprised of films carrying the themes of arts and artist or were literary adaptations. Among the thirteen that competed for the Golden Tulip, Kôhî Jikô (Café Lumière, 2004) by Hou Hsiaohsien; Lila Dit Ca (Lila Says Yes) from France directed by Lebanese Ziad Doueiri (a follow-up to his successful debut, West Beirut); from Canada, Childstar (2004) by Don McKellar and Turkish director Erden Kiral's Yolda (On the Way, 2004) about Guney's last days in prisons drew attention.

The Galas, defined by the festival as the most crowd pleasing films included Woody Allen's Melinda and Melinda, Wong Kar Wai's 2046 and Mike Leigh's Vera Drake. Buster Keaton's 1927 film The General and George Fitzmaurice's The Son of the Sheik (1926) had special screenings.

The Unforgettable Directors section focusing on a film personality that passed away featured Pietro Germi. Tributes were made to Neil Jordan, Roman Polanski, Alain Robbe-Grillet and Turkish director Yavuz Turgul. John Waters was chosen for the Eccentrics of the Cinema section with screenings of Pink Flamingos (1972), Polyester (1981), Hairspray (1988) and A Dirty Shame (2004).

The From the World Film Festivals section showcased a good selection of films of the past year among which La Demoiselle d'honneur (The Bridesmaid, 2004) by Claude Chabrol and Exils (The Exiles, 2004) by Tony Gatlif from France and Daremo Shiranai (Nobody Knows, 2004) by Japanese Hirokazu Kore-eda and La face cachée de la Lune (Far Side of the Moon, 2003) by Robert Lepage from Canada were particularly interesting.

A special section was devoted to South Korean cinema featuring Samaria (Samaritan Girl, 2004) by Kim Ki-duk and Haryu Insaeng (Low Life, 2004) by Im Kwon-taek among the nine films included.

The glory and the glamour were certainly not absent with Sophia Loren, Harvey Keitel and Jane Campion heading the prestigious guest list. But what drew many of the foreign press and festival delegates to Istanbul was the recent crop of Turkish films, particularly the return of Erden Kiral after a very long silence with Yolda (On the Way); a new film from Ali Özgentürk, Kalbin Zamani (The Time of the Heart) and another new film by 83-year old Atif Yilmaz, Eğreti Gelin (The Borrowed Bride) side by side with first features such as Yazi Tura (Toss Up) by Uğur Yücel and Balans ve Manevra (Balance and Movement) by rock-star Teoman.

A coming-to-terms with a problematic past event? Self-introspection of an artist carrying the deep wound of rejection? A homage to a revered master? Yolda is all of these things and more. Made twelve years after Mavi Sürgün (The Blue Exile) and twenty-two years after Hakkaride Bir Mevsim (A Season in Hakkari), On the Way carries the basic themes of the two previous works - prison-exile and diverse aspects of freedom and imprisonment, physical as well as spiritual and metaphorical; the alienation of the intellectual in an industrialised society; and a long journey that runs parallel to an interior journey of settling of accounts with the heavy burden of memories.

Whereas in A Season in Hakkari the journey ends in a world that is entirely opposite the world of the intellectual but nevertheless a mirror of his soul and the journey in The Blue Exile culminates in the writer becoming one with nature, in On the Way, the journey of the artist is endless, effectively drawn in the scene when the protagonist and his guards drive in circles in the heavy fog trying to find the prison that would incarcerate one of the most important artists of Turkey - novelist, screenwriter, actor and director, Yilmaz Güney.

While Güney was in jail, Yol was directed by Şerif Gören, one of his apprentices, with detailed instructions from the master. Originally, this job was entrusted to Erden Kiral but after seeing some of the rushes, Güney 
unexpectedly stopped the shooting and changed directors. Traumatised by the event, Kiral wrote a long letter to Güney, which he never sent. Had he sent that letter, Kiral explained to me, he would not have made this film today. "Although one cannot create without admiration of great masters and their works, admiration slows down the thinking process. You can become a master only by killing the master."

The reaction to the film was rather cool in Turkey. Yilmaz Güney is a legend and unwritten taboos that are not easily broken. Many comparisons were made to actual events and found lacking. Some critics claimed that the film would not be possible to understand by those not familiar with the actual story. However, On the Way has been invited to several prestigious film festivals and more favourably received by those not familiar with the details who can judge the work for its own merit.

The film of Ali Özgentürk, on the other hand, is a nostalgia film, which takes places, appropriately, in the legendary Art Nouveau hotel of Istanbul, the Pera Palas. The story that spans about five decades is told by two detectives, one of who still carries the burden of not having solved a crime committed twenty years ago. At the centre of it all is a beautiful woman, loved by three men. The performance of some of the first class actors of Turkish cinema is the strongest point of the film, particularly Hülya Avşar, the heart-throb of all three men, who ages so gracefully. And Birol Ünel, who was last seen in Fatih Akin's Against the Wall adds to the eccentric atmosphere. The tempo of the film is not for everyone but The Time of the Heart may easily become a cult film one day.

The favourite of everyone no doubt was The Borrowed Bride. Based on an old custom that may or may not have existed, of hiring experienced women to prepare young boys for marriage, The Borrowed Bride is an upbeat, romantic period piece about forbidden love, sensuality and hypocritical mores of society. Atif Yilmaz, the director of 'women's films' did it again!

Unfortunately, none of the films from the younger generation could match the masters.

\section{References}

\section{AWARDS}

The Golden Tulip Award in the International Competition (ex aequo)

La femme de Gilles (Gilles' Wife) by Frédéric Fonteyne (Belgium-France-Luxembourg-Italy-Switzerland) and Kôhî Jikô (Café Lumière) by Hou Hsiao-hsien (Japan-Taiwan)

\section{The National Competition:}

The Best Turkish Film of the Year Award: Anlat İstanbul (Istanbul Tales) Ümit Ünal, Kudret Sabanci, Selim Demirdelen, Yücel Yolcu and Ömür Atay

The Best Director of the Year Award: Uğur Yücel for Yazi Tura (Toss-Up)

The Best Actor Award: Olgun Şimşek for Toss-Up

The Best Actress Award: Yelda Reynaud for Istanbul Tales

\section{The FIPRESCI Award}

In the International Competition: Innocence Lucile Hadzihalilovic (Belgium-France-UK)

In the National Competition: to Meleğin Düşüsü (Angel's Fall) Semih Kaplanoğlu

\section{People's Choice Awards}

Innocence, Lucile Hadzihalilovic (Belgium-France-UK) in the International Competition, and Toss-Up by Uğur Yücel in the National Competition 


\section{Author Information}

Gönül DÖNMEZ-COLIN is an independent researcher and writer whose publications include Women, Islam and Cinema, Cinemas of the Other: A personal Journey with Filmmakers from the Middle East and Central Asia, Cinema of North Africa and the Middle East (ed.); Turkish Cinema: Identity, Distance and Belonging (Reaktion Books), and Routledge Dictionary of Turkish Cinema (2014). 